Omelicheva, Mariya Y. Resolved: Academic Debate Should Be a Part of Political Science Curricula, Journal of Political Science Education 3:161-177, 2007. Publisher's Official Version <http://dx.doi.org/10.1080/15512160701338320>.

Open Access Version: <http://kuscholarworks.ku.edu/dspace/>.

[This document contains the author's accepted manuscript. For the publisher's version, see the link in the header of this document.]

\title{
Resolved: Academic Debate Should Be a Part of Political Science Curricula
}

\author{
Mariya Y. Omelicheva
}

\author{
Paper citation: \\ Omelicheva, Mariya Y. Resolved: Academic Debate Should Be a Part of Political Science \\ Curricula, Journal of Political Science Education 3:161-177, 2007.
}

Keywords: debate, critical thinking, action research

\begin{abstract}
:
Should political science educators use debate for teaching their undergraduate students? This paper argues for incorporation of academic debate into curriculum of undergraduate courses. It demonstrates the process of arriving at a decision favorable of debate through exploration and analysis of competitive reasons, arguments, and evidence for and against using academic debate as a method of teaching and learning. Empirical evidence for assessing strengths and limitations of academic debate was collected in the undergraduate political science classes by means of educational action research. A corollary of the study is that potential problems of debates should not deter educators from using this instructional technique. The knowledge of debate's weaknesses can assist in improving the effectiveness of this teaching strategy in promoting students' skills of critical thinking, and understanding of complex political issues. Awareness of obstacles to academic debate can help to implement this method of instruction in a way which is positive and non-threatening to students.
\end{abstract}


Omelicheva, Mariya Y. Resolved: Academic Debate Should Be a Part of Political Science Curricula, Journal of Political Science Education 3:161-177, 2007. Publisher's Official Version <http://dx.doi.org/10.1080/15512160701338320>.

Open Access Version: <http://kuscholarworks.ku.edu/dspace/>.

Resolved: Academic Debate Should Be a Part of Political Science Curricula, Journal of Political Science Education 3:161-177, 2007

\section{Resolved: Academic Debate Should Be a Part of Political Science Curricula}

Mariya Y. Omelicheva

Department of Political Science, Purdue University

Beering Hall of Liberal Arts and Education

100 University Street, room 2249

West Lafayette, IN 47907-2098

Phone: (765) 494-4161

Fax: (765) 494-0833

Cell: (765) 418-0493

email: omeliche@purdue.edu

website: http://web.ics.purdue.edu/ omeliche/home page.htm

Mariya Omelicheva is a PhD candidate at the Department of Political Science, Purdue University. She holds a law degree in international law and a certification for teaching human rights law and government from Russia. Since 2001, she has been instructing undergraduate courses in political science at Purdue University. In her scholarship of teaching, she focuses on the issues of students' assessment and application of various research techniques to the analysis of learning outcomes. In 2005, she received the Purdue University Excellence in Teaching Award. 
Should political science educators use debate for teaching their undergraduate students? This paper argues for incorporation of academic debate into curriculum of undergraduate courses. It demonstrates the process of arriving at a decision favorable of debate through exploration and analysis of competitive reasons, arguments, and evidence for and against using academic debate as a method of teaching and learning. Empirical evidence for assessing strengths and limitations of academic debate was collected in the undergraduate political science classes by means of educational action research. A corollary of the study is that potential problems of debates should not deter educators from using this instructional technique. The knowledge of debate's weaknesses can assist in improving the effectiveness of this teaching strategy in promoting students' skills of critical thinking, and understanding of complex political issues. Awareness of obstacles to academic debate can help to implement this method of instruction in a way which is positive and non-threatening to students.

Key words: debate, critical thinking, action research 
Omelicheva, Mariya Y. Resolved: Academic Debate Should Be a Part of Political Science Curricula, Journal of Political Science Education 3:161-177, 2007. Publisher's Official Version <http://dx.doi.org/10.1080/15512160701338320>.

Open Access Version: <http://kuscholarworks.ku.edu/dspace/>.

Universities have always recognized the importance of developing in young people the habit of independent, systematic, and well-reasoned thinking. For centuries, debate has been an important part of academic programs. In the Greek philosophy schools, mediaeval educational establishments, and modern universities alike debate has been used to enhance student learning and test their mastery of a subject area (Branham 1991; Freeley 1986; Potter 1963).

In American colleges academic debate has been widely used in forensics and speech classes. Recently, it became increasingly popular in the undergraduate courses in psychology, sociology, and history (Bauer and Wachowiak 1977; Budesheim and Lundquist 2000; Elliot 1993; Moeller 1985; Smith 1990). A vast number of teachers across the curricular acknowledge instructional benefits of this highly participatory teaching technique that provides students with opportunities to meaningfully talk, listen, interact, deliberate, read and reflect on the content, ideas, issues and concerns of an academic subject.

Should political science educators use debate for teaching their undergraduate students? I argue for incorporation of debate into curriculum of undergraduate courses. This premise follows my assessment of both contributions and limitations of debate and conscientious analysis of empirical evidence collected in the introductory political science classes by means of educational action research.

The effectiveness of academic debate for student learning has been established through experimental and observational research (Avery 2002; Bellon 2000, 169; Brembeck, 1949; Combs and Bourne 1994). Few studies, however, subjected educational usefulness of academic debate to debate, i.e., to a systematic analysis and evaluation of 
evidence, arguments, and opinions for and against using academic debate as a method of teaching and learning (Kruger 1968).

This study demonstrates the process of arriving at a judgment favorable of academic debate through exploration of competitive reasons for and against incorporation of debate into the repertoire of teaching methods. It utilizes knowledge of the obstacles to successful realization of debate for drawing practical recommendations on how to enhance the effectiveness of this teaching technique for student learning.

The structure of the paper follows the structure of a simple debate, which requires presentation of the opposite sides of an issue in an orderly manner. I begin by discussing arguments for and against incorporation of debates into undergraduate curriculum. The section that follows will describe action research methodology used for collecting evidence on the impact of academic debate on student learning. Next, I present and evaluate evidence that supports and challenges the acclaimed benefits of academic debate. Lastly, I incorporate the knowledge of things that can go awry in debate for drawing practical recommendations on how to make this teaching method a success.

Before I proceed, one caveat is in order. The title of this study uses the format of a typical debate resolution. A resolution is a specific statement or a question advanced for debate. Consequently, the verb "should" in the article's title is not meant to impose my liking of debate on other educators. Instead, the title invites all interested educators to consider educational benefits and drawbacks of debate and decide on the usefulness of this educational technique for student learning.

\section{Shall We Debate Politics? The Pros and Cons of Academic Debate}


Omelicheva, Mariya Y. Resolved: Academic Debate Should Be a Part of Political Science Curricula, Journal of Political Science Education 3:161-177, 2007. Publisher's Official Version <http://dx.doi.org/10.1080/15512160701338320>.

Open Access Version: <http://kuscholarworks.ku.edu/dspace/>.

In English, the term "debate" encompasses several meanings. It is used in a broad sense of everyday disputes by means of words or arguments. It also refers to a process of decision-making in a public deliberative body, such as a legislative assembly or a courtroom, in accordance with the strict rules of procedure. The kind of debate which concerns real-world rational decision-making is known as substantive debate. It is different from academic debate, which is a method of instruction on how to make a wellinformed judgment (Inoue 1996). Academic debate is conducted under the guidance of an educator or an educational institution with the purpose of teaching students skills necessary for judicious decision-making and effective participation in the discussion of public and personal issues.

Academic debate comes in a variety of formats and styles. It can be held face-toface or via the Internet, and in the teams of one, two, or more students. It can revolve around the issues of values, like Lincoln-Douglas debate, or issues of current interest, like Karl Popper debate. Academic debate can mimic substantive debate as in the Legislative and Parliamentary debates, mock trails, and cross-examinations of public policies. ${ }^{1}$

Regardless of the format, any academic debate starts with the presentation of the pro and con arguments related to the issue of debate. Following the established procedure, I will discuss reasons for and against incorporation of academic debate into the curriculum of undergraduate political science courses.

In Support of Academic Debate. The strongest argument for using academic debates zeros in on the acclaimed contributions of debate to three domains of student learning: (1) cognitive domain (development of critical thinking); (2) affective domain (generation of interest in the subject matter); and (3) a domain of skills and abilities 
Omelicheva, Mariya Y. Resolved: Academic Debate Should Be a Part of Political Science Curricula, Journal of Political Science Education 3:161-177, 2007. Publisher's Official Version <http://dx.doi.org/10.1080/15512160701338320>.

Open Access Version: <http://kuscholarworks.ku.edu/dspace/>.

(communication and teamwork skills) (Allen et al. 1999; Bauer and Wachowiak 1977; Brembeck 1949; Budesheim and Lundquist 2000; Byron, et al. 1993; Combs and Bourne, 1994; Green and Klug, 1990; Elliot 1993; Moeller 1985; Smith 1990).

The first, and most frequently cited educational merit of debate, is its capacity to enhance critical thinking of students. Critical thinking is an intellectually disciplined process of arriving at a decision that involves collection, synthesis, conceptualization, application, vigilant analysis, and prudent assessment of information accumulated through research, observation, personal experience, communication, as well as reflection, and reasoning (Scriven and Paul 2004).

A. Craig Baird (in Freeley 1971, 22) commented that, "the list of items comprising critical thinking sounds like the unit divisions of an argumentation course. Your arguers are weighing facts, generalizing, comparing, avoiding fallacies. The procedures of our students all add up to a method of studying and applying 'critical thinking'." At the preparation stage of academic debate, students develop a logical position that reflects the team's view on a subject and demonstrates recognition of the opposing view. Students amass evidence in support of their position and in refutation of the position of their opponents.

During academic debate, teams' positions are contested by those who hold different view points. These challenges generate uncertainty about the validity of students' ideas and create a state of internal "conceptual conflict" (Elliot 1993, 38). To resolve this cognitive dissonance, students look for additional evidence. Learners attempt to reconcile their own and opponents' arguments through improved reasoning and reassessment of their own position. The reconceptualization of positions and formulation 
Omelicheva, Mariya Y. Resolved: Academic Debate Should Be a Part of Political Science Curricula, Journal of Political Science Education 3:161-177, 2007. Publisher's Official Version <http://dx.doi.org/10.1080/15512160701338320>.

Open Access Version: <http://kuscholarworks.ku.edu/dspace/>.

of new perspectives is an outcome of research, deliberation, and reassessment (Johnson and Johnson 1988, 60).

In addition to the enhancement of critical thinking, academic debate generates student interest in social problems. Learners who have no desire to acquire and use new knowledge cannot obtain an in-depth understanding of complex issues and transferable skills of well-reasoned thinking (Silberman 1995) Consequently, affective side of learning experience, which includes students' interests, feelings, attitudes, and values, plays a crucial role in student learning. Academic debate throws students into rich, complex, and interactive experiences. It involves them into the examination of important social issues and search for solutions to social problems. Consequently, educational debate affords personally meaningful challenge and provides context for facing it (Angelo 1993; Caine and Caine 1991, 104-105). Thus, debate provides an opportunity for active involvement with the material that enhances students' learning process in a stimulating environment.

Finally, participation in academic debate teaches students a number of important skills such as the skills of verbal communication and teamwork. Preparing for a debate, students communicate their opinions and research findings to other team members. During the debate, students advocate their positions publicly. To excel in the debate, students must convey their knowledge to peers in a convincing and comprehensive way. Students sharpen their questioning skills through participation in cross-examination that makes debaters more capable of eliciting necessary information. The practice of verbal communication improves public speaking skills as well as overall learning (Caine and Caine 1991, 122). 
Omelicheva, Mariya Y. Resolved: Academic Debate Should Be a Part of Political Science Curricula, Journal of Political Science Education 3:161-177, 2007. Publisher's Official Version <http://dx.doi.org/10.1080/15512160701338320>.

Open Access Version: <http://kuscholarworks.ku.edu/dspace/>.

Many interpersonal teamwork skills, such as establishing linkages (communication, trust, etc.) with other team members, participating in collective activities of the team, and exercising leadership can be acquired and refined through the learning experiences of academic debate. At all stages of debate, students have to establish and maintain rapport and constructive dialogue with other team members. Debaters are urged to express their opinions in respectful ways and be tolerant and understanding of the opinions of others. To succeed in the debate, students must be able to negotiate their differences and commitments. They have to be willing to take on and delegate responsibilities and participate in collective activities, such as brainstorming or preparation of speeches.

Against Debating. Debate, as any educational technique, is not devoid of potential problems and limitations that can serve as barriers to incorporation of this teaching technique into educational programs. On the downside of academic debate is its propensity to inadvertently promote conflict, tension, and alienation in the classroom. The word debate comes from Old French debatre "to beat" (American Heritage Dictionary of English Language 2000). Many expressions used for describing argumentation in debate, such as "to attack" an opponents" position, "to destroy" or “demolish" opponents' arguments, resemble battleground vocabulary. A perception of debate as verbal warfare turns students off from debate (Byron et al. 1993).

Although the rules of debate encourage the orderly and unprejudiced examination of disputed claims, in-class debate can degenerate into a heated confrontation, especially when debate revolves around emotionally-charged issues deeply entrenched within 
Omelicheva, Mariya Y. Resolved: Academic Debate Should Be a Part of Political Science Curricula, Journal of Political Science Education 3:161-177, 2007. Publisher's Official Version <http://dx.doi.org/10.1080/15512160701338320>.

Open Access Version: <http://kuscholarworks.ku.edu/dspace/>.

students' belief systems. Such a confrontational mode of debate is not the most productive mode for student learning.

Additionally, a competitive element of academic debate can skew students' behavior and arguments. Interested in "beating" their opponents, debaters can employ various persuasive tactics to win the debate. Instead of promoting a better understanding of complex social issues and encouraging critical thinking, academic debates can mislead students and strengthen their existing views (Bourdillon 2004; Comstock 1968; Eliot 1993; Johnson and Johnson 1988).

The intensity of academic debate is one of its strengths but also potentially one of its weaknesses. Time constraints set for debaters' speeches, on-the-spot rebuttals, close monitoring of students' responses by their peers, and unpredictability of the opponents' line of argumentation can make learners nervous. The studies of affect and cognition show that negative affective experiences, such anxiety, are detrimental to student learning (Do and Schallert 2004).

Some educators who have observed academic debates note that students participating in debates do not always strive for objective evaluation of different sides of the debated questions. To be able to engage in critical thinking, students have to carry out extensive research, analysis, and reflection on various types of information related to different perspectives of the debated issues. Learners are often unable to get fully prepared (due to the complexity of issues addressed in debates, inability to foresee all of the nuances of the arguments their opponents will be making, and time constraints) for critical evaluation of the evidence and arguments presented in debates.

\section{Educational Action Research in Academic Debate: Collection of Evidence}


Omelicheva, Mariya Y. Resolved: Academic Debate Should Be a Part of Political Science Curricula, Journal of Political Science Education 3:161-177, 2007. Publisher's Official Version <http://dx.doi.org/10.1080/15512160701338320>.

Open Access Version: <http://kuscholarworks.ku.edu/dspace/>.

I examined the claims of proponents and opponents of academic debate by means of educational action research. ${ }^{2}$ Several attributes separate action research from other types of research. First, it is an informal, qualitative, and interpretive method of inquiry, which does not aim at finding statistically significant relationships or developing a theory. Second, action research takes place in real-world situations, and aims at solving real-life problems; therefore, the emphasis of action research is on practical significance of its findings. Lastly, action research allows different research tools to be used for collecting and analyzing data. These various methods, which are common to the qualitative research paradigm, include collection and analysis of documents, participant observation recordings, and interviews among others (O’Brien 1998).

Educational action research has all of the features of action research. Its purpose is to accumulate evidence-based critical accounts of educational practices in order to improve teaching, to test educational theory, or to evaluate and implement different teaching techniques and educational plans (Walker and Warhurst 2000, 35). Educational action research fuses the scholarship of teaching and discovery. It does not interfere with normal educational process because evaluations of students' performance can be a part of the action research strategy, and assessment of educational process can be embedded into the classroom curriculum. The flexibility of the action research design makes it responsive to changes that an instructor introduces to her curriculum based on the reflection on teaching practices and the analysis of collected evidence on learning outcomes.

Different data collection techniques and methods for their analysis can be used in educational action research. For the purposes of analysis of academic debates I collected 
Omelicheva, Mariya Y. Resolved: Academic Debate Should Be a Part of Political Science Curricula, Journal of Political Science Education 3:161-177, 2007. Publisher's Official Version <http://dx.doi.org/10.1080/15512160701338320>.

Open Access Version: <http://kuscholarworks.ku.edu/dspace/>.

and analyzed the following types of evidence: reaction essays of the debaters, students' reflections on debates, my personal records of students' performance in debates, and reflective conversations I had with my colleagues that I invited to be external judges in debates. The evidence was collected over the course of three semesters from three undergraduate classes in a large-size public research university.

Examining the evidence collected in my classes, I tried to answer the following questions: Do students have a clear understanding and sufficient knowledge of the issue area of debate? Are their arguments logical, coherent, and straightforward? Do students demonstrate understanding of the opposite perspectives on the issue? Are they able to see strengths and flaws in the arguments on both sides of the issue? With regard to the students directly involved in debates, I assessed their ability to deliver arguments with the right emphasis, confidence, enthusiasm, and in the absence of mannerism and offensive comments. Additionally, I used the collected evidence to assess a degree of "teamness" achieved by debate teams.

Over the course of three semesters, I conducted 12 academic debates. The goals of educational debates corresponded to the goals of the courses I taught. By means of debating over contentious questions I wanted to familiarize my students with a range of controversial political issues, and raise their awareness of the existence of different perspectives and approaches to their resolution. I aspired to encourage students to start questioning the presented information and to facilitate their critical thinking.

Participation in debates in the capacity of a debater and as a member of the audience was one of the course requirements. At the beginning of the semester, students received explicit guidelines elaborating the rationale for debates, explaining debate's 
Omelicheva, Mariya Y. Resolved: Academic Debate Should Be a Part of Political Science Curricula, Journal of Political Science Education 3:161-177, 2007. Publisher's Official Version <http://dx.doi.org/10.1080/15512160701338320>.

Open Access Version: <http://kuscholarworks.ku.edu/dspace/>.

format, procedures, topics, and grading policies. Following the general educational practice, I let my students choose topics and positions in debates and took their preferences into consideration when I was forming debate teams.

Each debate had two teams, a pro and a con team, consisted of 4-6 students. The teams were required to carry out extensive research on an assigned issue prior to debate. Debaters had to meet outside of the class to discuss their debate strategies, and prepare effective arguments in support of the team's position and in refutation of the position of their opponents. I provided students with lists of recommended readings and suggested to do additional research on their topics. Besides debates' guidelines and suggested readings, I handed out evaluation scales or evaluation rubrics containing criteria and descriptions of points to be observed in order to gauge students' performance during debates.

I modified a rather complicated structure of formal debate consisting of two affirmative constructive speeches, two negative constructive speeches, two crossexaminations, and two rebuttals delivered in a certain order and during fixed time slots (Freeley 1986). Since I wanted debaters to practice argumentation as well as the skill of questioning their opponents, I kept one constructive affirmative speech and one negative constructive speech, as well as one rebuttal and one round of cross-examinations. I also planned to have more class participation in debates. Therefore, I allotted enough time for questions from the audience. Since many students in my classes were not familiar with the terminology of formal debate, I used more common vocabulary in describing stages and procedures of debates. 
In addition to participation in a debate, debaters were required to write a reaction paper discussing their debate experience. Students that were not participating in the debate directly were asked to prepare debate briefs in which they had to summarize each side's position, indicate which arguments were most persuasive, and tell whether and why they agreed with one position or another. The purpose of reflective papers was to motivate students' attendance and participation in debates. Another goal of debate reflections was to promote students' disciplined thinking and learning. Since debates were an integral part of action research, I used students' reflections as an important source of data for analysis and assessment of debates' educational functions.

In one semester, I invited my colleagues interested in debate topics to be external judges (one external judge per debate). The judges were asked to provide constructive critique of participants at the end of debate and assist me in producing a more reliable evaluation of debaters.

Students received both an individual and a team grade for their performance in debates. In evaluating each team's work, I took into consideration the comments of an external judge and critical remarks from other students. To assign individual grades, I asked each member of a team to evaluate the performance of other members of the team. I used those peer evaluations for making adjustments to teams' grades so that they accounted for the individual contributions to the group work. Peer evaluations remained anonymous outside of being read by the instructor.

What Can and Cannot Be Achieved Through Academic Debate: Analysis of Evidence From Undergraduate Political Science Courses 
In Support of Debates' Contributions to Student Learning. The analysis of evidence that I collected in my classes afforded some support to educational benefits of debates. Debaters' average scores assessing different areas of critical thinking ranged from 2.53 to 2.64 on a 3-point scale (see Table 1 below). My colleagues who observed 5 debates in the capacity of judges agreed with my assessment of students' performance in debates.

Table 1. Assessment of Debaters' Performance

\begin{tabular}{|l|l|l|l|l|l|}
\hline \multicolumn{1}{|c|}{ Criteria } & N* & Min & Max & Mean & St. Deviation \\
\hline Understanding of both perspectives on & 24 & 2.3 & 3.0 & 2.627 & 0.235 \\
\hline complex issues & & & & & \\
\hline Organization of arguments & 24 & 2.3 & 3.0 & 2.644 & 0.218 \\
\hline Evidential support & 24 & 2.2 & 3.0 & 2.567 & 0.211 \\
\hline $\begin{array}{l}\text { Ability to see flaws in and respond to } \\
\text { opponents' arguments }\end{array}$ & 24 & 2.1 & 3.0 & 2.528 & 0.249 \\
\hline
\end{tabular}

* The assessment was carried out in 12 debates, which involved 24 debate teams.

My records of the students' performance and debaters' reactions to debates also demonstrate that debates engaged students in the intellectual practices that characterize critical thinking. The debaters had to gather and assess relevant information on the topic, including evidence supporting a counter position. To succeed in the debate, students had to have an ability to anticipate and examine rebuttals from their opponents. As one of the students pointed out, "[debate] offered good practice in researching a specific topic, as well as trying to infer what the other team would question by researching their side of the argument. This is a very important skill to be able to master.” Others students commented 
Omelicheva, Mariya Y. Resolved: Academic Debate Should Be a Part of Political Science Curricula, Journal of Political Science Education 3:161-177, 2007. Publisher's Official Version <http://dx.doi.org/10.1080/15512160701338320>.

Open Access Version: <http://kuscholarworks.ku.edu/dspace/>.

on how much effort they put into the examination of different sides of an issue, "I wanted to know as much as I could about both sides of the argument so I would not look stupid;" "I spent much of the week studying his writings and articles about him thinking they would have tried to pound us over the head with Leo Strauss."

Some debates' participants remarked that listening to opponents' viewpoints caused them to reassess their personal opinions leading to the change in attitudes on debated issues. As one student wrote, "I still agree with the position defended by the first team, but the team of opponents did have some facts that threw me off. The last debate was a memorable one." Another debater noted, "I most definitely took away some new thoughts and ideas of my own having heard all the arguments and done all the research." "Prior to this debate I would have originally agreed with team one's position regarding constraints on the freedom of speech. Although, I still feel that this is true.... I have a much greater respect for the idea of restraints and appreciate that it is necessary. ... I understand now how important it is to maintain pubic order through the restraint of the freedom of speech," commented another student.

Debates fostered a deeper understanding of the opposite sides of a debated issue among those students who participated in debates as members of the audience. In their reflections, students noted flaws in reasoning, deficiencies of evidential support, and persuasive tactics used by debate teams. For example, following the debate on American ideologies, about one quarter of students challenged debaters on the appropriateness of using certain examples in support of the team's arguments. The following comment is representative of these students' critique, "The group two used as their examples of traditional conservatives George Bush and the Christian Coalition... I felt neither of them 
Omelicheva, Mariya Y. Resolved: Academic Debate Should Be a Part of Political Science Curricula, Journal of Political Science Education 3:161-177, 2007. Publisher's Official Version <http://dx.doi.org/10.1080/15512160701338320>.

Open Access Version: <http://kuscholarworks.ku.edu/dspace/>.

were appropriate embodiments of the classical conservative idealists." Following the debate on the freedom of speech, a half of the students questioned the suitability of an example of a hate group crime for demonstrating the negative aspects of the concept and idea of free speech. Students often pointed to the aspects of a topic that they thought a team should have addressed but did not, and asked questions that they did not have an opportunity to ask during debates.

Thus, the documented evidence provides some support to the connection of critical thinking and debate. This corresponds to the findings of earlier studies of critical thinking (Allen et al. 1999; Bellon 2000; Brembeck 1949; Colbert 1987). In one of the recent surveys of 24,837 students, researchers also found that key components of debates, such as independent research, team work, and class presentation, promote self-reported growth in critical thinking (Tsui 1999).

Promoting critical thinking is not the only goal of academic debates. Educators use debates to advance students' understanding of complex issues. In my classes, almost every student observed how much he or she learned in debates. One student shared, "The debate was a good experience because it forced us to look at both sides of an argument. In most classes, when we are taught about contemporary issues, we only look at one side. The debate allowed us to look at both points of view." Some reported that debates forced them "to make use of research tools while being involved in a process which brought out facts which would not normally be brought out in class."

Debates in my classes generated overwhelming student interest. Every single debater and the majority of students commented on "exciting", "enlightening", "positive", etc. experience with academic debates. Many students commented that they 
Omelicheva, Mariya Y. Resolved: Academic Debate Should Be a Part of Political Science Curricula, Journal of Political Science Education 3:161-177, 2007. Publisher's Official Version <http://dx.doi.org/10.1080/15512160701338320>.

Open Access Version: <http://kuscholarworks.ku.edu/dspace/>.

found debates to be fun, yet, informative. Others wrote that they appreciated the opportunity to weigh the evidence simultaneously for both sides of each issue.

I received no criticism of academic debate as an instructional technique. One of the common complaints expressed by the students in 50-minutes long classes was that the debates were rushed and that not enough time was available for questions and answers. Related to constraints of time were the complaints about inability to use all of the researched sources. As one of the students noted, "A lot of my disappointment came from the fact that I wasn't able to use much of the material, which I had prepared for, but that's probably true with any debate." Even those students who personally disliked the subject enjoyed participating in debates.

Academic debates also contributed to the development of students' presentation skills and abilities to work in teams. In their comments students wrote that debates made them increasingly aware of how much courage and training it takes to prepare oneself for speaking intelligently in public. Some students realized that mastering the skill of presentation takes practice. As one of the debaters pondered, "After the debate the only thing I thought about was how I wished I could do it over again. I did not think I did a bad job necessarily; however, I do feel that having participated in one debate I could do a better job in the next debate."

Many students expressed enthusiasm about teamwork, "It was fun working as a group and formulating our different arguments and strategies for the debate;" or, "we had 2 weeks ... to combine our efforts to come up with coordinated arguments... All of my team members were great to work with." Working with peers was an enlightening experience for many students. This is where they thought they learned the most, "The 
Omelicheva, Mariya Y. Resolved: Academic Debate Should Be a Part of Political Science Curricula, Journal of Political Science Education 3:161-177, 2007. Publisher's Official Version <http://dx.doi.org/10.1080/15512160701338320>.

Open Access Version: <http://kuscholarworks.ku.edu/dspace/>.

best part of the debate was the preparation. Our team worked together to formulate ideas and develop a strategy, which we thought we could argue effectively." Reflections on the teamwork helped to identify hurdles for collaborative learning. One team member wrote, "Some of my fellow team members are very intelligent and informed people, but because of this I felt that they overshadowed the rest of the team... I enjoyed hearing the views of these people, but because of their previous knowledge and firm beliefs on the topic, they took control during the debate..."

The considered evidence indicates that debates conducted in my classes stimulated critical thinking, the skills of oral communication, and teamwork in learners. A number of students acquired a good grasp and appreciation of complex political issues. Debates generated considerable student interest in momentous political and social issues.

Where Debates Fail to Succeed: Evidence Against Educational Benefits of Academic Debates. The merits of academic debate should not be exaggerated. My personal and other educators' experience with debates revealed a number of limitations of this educational technique.

Critical thinking, one of the postulated goals of educational debate, entails modification of one's decision in light of sufficient and reliable evidence supporting a counter position (Gelder 2005, 46). In my classes, debaters rarely admitted that arguments and evidence presented by the team of opponents changed their position on the debated issue. If these students were the members of a "losing" team, they tried to defend themselves instead of reflecting critically and analytically on flaws in their arguments. Only a few debaters acknowledged that the team of opponents "won" the debate because it had better evidence and arguments in support of its position. Among members of the 
Omelicheva, Mariya Y. Resolved: Academic Debate Should Be a Part of Political Science Curricula, Journal of Political Science Education 3:161-177, 2007. Publisher's Official Version <http://dx.doi.org/10.1080/15512160701338320>.

Open Access Version: <http://kuscholarworks.ku.edu/dspace/>.

audience, only a small percentage of students (2-5\%) changed their initial opinions on the subject of debate after listening to alternative points of view, as reflected in the pre- and post-debate votes and students' comments.

Some debaters in my classes resorted to tricky persuasion practices in order to "win" support of the audience. In the debate over the US position on the International Criminal Court (ICC), a team arguing that the US should not accept the ICC tried to convince the audience to accept their position by appealing to students' sense of patriotism. The team argued that joining the ICC would jeopardize lives and freedoms of American soldiers serving abroad and that supporting the ICC would mean withdrawing support from American troops. From team's reflection on this debate, I learned that members of the team chose this strategy because they wanted to win the debate. As one of the debaters stated in his reaction paper, "it was a great way to persuade them [the audience] to our side. It made the other group seem un-American for supporting the ICC." The tactic of that team set some members of the audience against the team of opponents.

In another debate on the American policy toward the Kyoto Protocol, a team debating against US joining international environmental treaties used the following persuasive tactic. It argued that about $1 / 3$ of greenhouse gases in the country are produced by American consumers. Big cars - trucks and SUVs - are the chief pollutants. Joining the Kyoto Protocol will impact the life-style of many American people who will have to exchange their gigantic vehicles on smaller cars. A few members of the audience jumped off their chairs when they heard of the prospect of giving up their trucks. From a conversation with a debater who delivered this persuasive message I found out that, in a 
Omelicheva, Mariya Y. Resolved: Academic Debate Should Be a Part of Political Science Curricula, Journal of Political Science Education 3:161-177, 2007. Publisher's Official Version <http://dx.doi.org/10.1080/15512160701338320>.

Open Access Version: <http://kuscholarworks.ku.edu/dspace/>.

persuasion class, this student was taught to speak to the audience, its wants, and needs. He said that he noticed a large number of "red-necks" (to use the words of the student) and thought of an argument against the Kyoto Protocol that could be relevant and understandable to those truck-drivers.

The majority of students listening to debates as members of the audience were unable to distinguish well-reasoned argumentation from persuasion. They succumbed to persuasive and emotional, albeit, invalid, tactics and evidence resorted to by the teams. Consequently, those debates, in which emotionally-laden persuasion was used, provided no careful analysis of the opposite viewpoints on debated issues.

Although, no debate conducted in my classes degenerated into "verbal warfare," some debaters and members of the audience, at times, broke good composure. Their hustled comments, raised voice, and personal attacks heated up classroom atmosphere. Additionally, 5 students in my classes reported anxiety over debates. The following comment is representative of fears shared by those students, "the experience of the debate was rather exhilarating, but at the same time it was kind of stressful because you had everyone in the classroom looking at you and waiting for your next question or comment."

The observed evidence suggests that academic debates do not always benefit every student's learning. It may be premature to conclude that all educational effects of debates are uniformly positive.

How Debating Educational Effectiveness of Academic Debate Can Assist in

\section{Improving Its Quality}


Omelicheva, Mariya Y. Resolved: Academic Debate Should Be a Part of Political Science Curricula, Journal of Political Science Education 3:161-177, 2007. Publisher's Official Version <http://dx.doi.org/10.1080/15512160701338320>.

Open Access Version: <http://kuscholarworks.ku.edu/dspace/>.

The discussed limitations of academic debate are potentially damaging to educational effectiveness of this teaching technique. However, these problems are preventable when some effort is put into devising the conditions of debate. The knowledge of the things that can go awry in debates can be used to facilitate their contributions to student learning. Awareness of obstacles to academic debate can assist in implementing this method of instruction in a way which is positive and non-threatening to students. What follows is a series of recommendations on how to increase the effectiveness of debates in promoting students' skills of critical thinking, and understanding of complex issues, and how to prevent adverse effects of academic debate on students.

To promote critical thinking by means of educational debate, instructors need to articulate critical thinking as one of the goals of academic debate, explain to students what it means, and demonstrate the skill in a series of exercises or examples. At the same time, instructors should underscore that "winning" is not an objective of academic debate and emphasize debate's educational values (Elliot 1993, 35; Thompson 1968).

Unless repeatedly reminded of the non-competitive philosophy of academic debate, students will be likely to view it as a contest and try to defeat their opponents. The better the students understand debate's goals, the more they will benefit from it, and the more enjoyable their debate experience will be (Thompson 1968). My students' written reactions to debates support this proposition. When students viewed the debate as a way to educate themselves and others on a given topic, they were more likely to invest greater effort into the analysis of information supporting their opponents' views. These 
Omelicheva, Mariya Y. Resolved: Academic Debate Should Be a Part of Political Science Curricula, Journal of Political Science Education 3:161-177, 2007. Publisher's Official Version <http://dx.doi.org/10.1080/15512160701338320>.

Open Access Version: <http://kuscholarworks.ku.edu/dspace/>.

teams would also be likely to choose more cooperative tactics of defense of their positions in debates.

The knowledge and understanding of educational goals of debate is not sufficient for its success. Students have to be aware of their roles in academic debates. Educators should provide debaters with explicit instruction on investigation of both sides of a debated proposition. It is important to remind debaters that their role in the debate is to present and examine different sides of an issue in an orderly manner, not to convince others to accept their position and arguments. Other students should be advised to compare and contrast opposite arguments before making a decision in support of one position or another.

To facilitate students' understanding of their role in academic debates, it has been suggested to inform students of the difference between persuasion and debate (Bourdillon 2004, 263). Persuasion differs from debate in that its sole goal is to convince the audience in one's point of view. Consequently, persuasion consists of one-sided arguments that are often based on the ethical and emotional appeals. In the debate, different sides of view are subjected to careful examination in order to arrive at a best decision possible.

The choice of debate topics and the formulation of debate propositions can affect the effectiveness of debates for students' learning. When instructors select topics for debates, they should be realistic about students' ability to manage the content of issues. The question or a proposition for debate has to be unambiguous and allow for the preparation of two well-documented positions (Johnson and Johnson 1988, 60). This will help students to deal with the complexity of issues. It will also reduce students' fears about the volume of work they have to complete. In addition, to help students manage 
Omelicheva, Mariya Y. Resolved: Academic Debate Should Be a Part of Political Science Curricula, Journal of Political Science Education 3:161-177, 2007. Publisher's Official Version <http://dx.doi.org/10.1080/15512160701338320>.

Open Access Version: <http://kuscholarworks.ku.edu/dspace/>.

complex political controversies, some instructors suggest constraining a choice of sources to those they have studied. Not only does it make educators better judges of students' preparation for debates, but also allows them to test the skill of application of new material to what students have learned (Moeller 1985).

To assuage student's fears and uneasiness with debates, instructors, again, need to be very explicit about the goals of debates and their expectations from debaters. My records indicate that students' perceptions of debates can affect their attitudes toward debates. When students interpret debate as a "win-lose" situation, they express more anxiety and concerns about losing the debate.

The planning and preparation process for debates should begin at the beginning of semester, especially, if the requirements for research are intensive. Some educators recommend encouraging students to share the main points that they will be making in debates with their opponents. This tactic can reduce anxiety and improve the quality of debates $^{3}$. Other instructors suggest assigning no grades for debate performance (Elliot 1993, 35), or, at least, making students aware that the merit of their arguments would not be evaluated solely in terms of debaters' ability to persuade the audience (McBath 1963, 8).

Additionally, students should be instructed to defend their positions in nonaggressive and non-humiliating ways. It may be necessary to remind students about the proper tone and body language, and convey the inappropriateness of the laughter and sarcastic comments, which can trivialize and undermine interesting viewpoints. Some educators suggest having a discussion of how debate may bring about negative emotions that are almost unavoidable in debate. When students' fundamental beliefs are challenged 
Omelicheva, Mariya Y. Resolved: Academic Debate Should Be a Part of Political Science Curricula, Journal of Political Science Education 3:161-177, 2007. Publisher's Official Version <http://dx.doi.org/10.1080/15512160701338320>.

Open Access Version: <http://kuscholarworks.ku.edu/dspace/>.

by opponents, these criticisms are often perceived as personal attacks (Bourdillon 2004, 264).

\section{Conclusion}

An argument proposed in this study is that academic debate can be exploited at the university level for promoting a range of intellectual, affective, and practical skills, such as critical thinking, deeper understanding of debated issues, the skills of communication and teamwork, and student interest in the subject of politics (Avery 2002; Bellon 2000, 169; Hess 2004, 257).

Along with the demonstration of different educational benefits of academic debate, this study examined arguments and evidence highlighting limitations of this method of instruction. It utilized the knowledge of potential problems associated with academic debate to draw practical recommendation on how to increase the effectiveness of this educational technique.

In a nutshell, examining the evidence collected in three introductory political science classes by means of action research, I was able to discern some critical thought, and heightened understanding of debated issues in learners. The students reported that debates were helpful for practicing the skills of presentation and teamwork. All students enjoyed participating in debates. For many students, alas, not all, debates became an excellent tool of learning. For me, debates turned out to be a superior tool of instruction and evaluation. Gauging students' performance in debates, I could measure their achievements, diagnose learning problems, and learn more about students' perspectives and attitudes towards the studied material. Critical reflections on my students' debate 
Omelicheva, Mariya Y. Resolved: Academic Debate Should Be a Part of Political Science Curricula, Journal of Political Science Education 3:161-177, 2007. Publisher's Official Version <http://dx.doi.org/10.1080/15512160701338320>.

Open Access Version: <http://kuscholarworks.ku.edu/dspace/>.

experience allowed me to learn more about the aspects of debate that are crucial for making this educational technique work.

Notwithstanding ample empirical support to educational effectiveness of debates, it will be mistaken to conclude that all educational effects of academic debates are uniformly positive. Debates conducted in my classes did not benefit every student's learning. Some students failed to acquire a deeper understanding of controversial issues or practice the skill of critical thinking, and others reported fears and anxieties over academic debates.

The observed limitations of academic debate should not deter educators from using this instructional technique in their classrooms. One of the corollaries of this study is that it is possible to realize the promised benefits of academic debate after some effort is put to design the conditions of debate and clarify its real purposes to students. Instructors should try to avoid turning academic debate into a contest debate. The latter is a format of debates that is utilized in high school and college debate teams traveling and debating against each other competitively in debate tournaments. The emphasis of academic debate should be placed on the development of important thinking skills and attitudes, such as interest in social problems and tolerance of differing viewpoints, and conditions of academic debate should be set for the achievement of these goals.

Another corollary of this research is that with all of its limitations, in practice, debate should not be used in isolation from other teaching techniques - lectures, discussions, papers, etc. - that can be used to capitalize on the strengths and correct for the weakness of academic debate. For instance, academic debate can stimulate discussion and generate student interest in the subsequent lectures. When things go awry in debates, 
as in the situation in which debaters mislead students with persuasive but invalid tactics, it is instructor's responsibility to inform students on the missed aspects of an issue in the follow-up lecture or discussion. Whenever the instructor diagnoses an area of knowledge where students continue to lack understanding after the debate is over, she should fill those gaps in students' knowledge using other teaching methods.

Finally, aspiring to teach our students complex cognitive skills, we should not expect major transformations in the ways our students think over a semester or two. Neither teaching techniques is capable of turning undergraduate students into critical thinkers because many skills are developed throughout the lifetime. Yet, the practice of those skills can make an important difference. Engaging in the skills itself by means of participation in educational activities designed to improve performance in the skill is an important step in mastering the skill. Academic debate has much to offer students in skills development, effective decision-making, and recognition and understanding of politics. Political science educators should take advantage of the valuable opportunities provided by debate for engaging students in learning about different aspects of politics, finding answers to personally meaningful political questions, negotiation of differences in their opinions, and collaboration toward constructive solutions.

\section{References}

Allen, M., Berkowitz, S., Hunt, S., and Louden A. 1999. “A Meta-Analysis of the Impact of Forensics and Communication Education on Critical Thinking." Communication Education 48(10):18-30.

American Heritage Dictionary of English Language. 2000. $4^{\text {th }}$ ed. Boston: Houghton Mifflin. 
Omelicheva, Mariya Y. Resolved: Academic Debate Should Be a Part of Political Science Curricula, Journal of Political Science Education 3:161-177, 2007. Publisher's Official Version <http://dx.doi.org/10.1080/15512160701338320>.

Open Access Version: <http://kuscholarworks.ku.edu/dspace/>.

Angelo, Thomas A. 1993. “A “Teacher's Dozen”: Fourteen General, Research-Based Principles for Improving Higher Learning in Our Classrooms.” AAHE Bulletin (April):58.

Avery, P.G. 2002. "Political Tolerance, Democracy and Adolescent." In Education for Democracy: Contexts, Curricula, Assessments, ed. Walter C. Parker. Information Age Publishing, 113-130.

Bauer, Gene and Dale Wachowiak. 1977. "The Home-Court Advantage: a Debate Format for the Teaching of Personality." Teaching of Psychology 4(4):190-193.

Bellon, Joe. 2000. "A Research-Based Justification for Debate across the Curriculum." Argumentation and Advocacy 36:161-175.

Bourdillon, Michael. 2004. “Conditions for Constructive Debate.” South African Journal of Science 100(May/June):263-165.

Branham, Robert James. 1991. Debate and Critical Analysis: The Harmony of Conflict. Hillsdale, NJ: Lawrence Erlbaum Associates.

Brembeck, W.L. 1949. “The Effects of a Course in Argumentation on Critical Thinking Ability." Speech Monographs 16:177-189.

Byron, Shelagh, Laurence Goldstein, David Murphy, and Elfed Roberts. 1993. "Interdisciplinary Dimensions of Debate." Hong Kong Papers in Linguistics and Language Teaching (16):31-52.

Budesheim, Thomas Lee, and Arlene R. Lundquist. 2000. "Consider the Opposite: Opening Minds Through In-Class Debates on Course-Related Controversies." Teaching of Psychology 26(2):106-110. 
Omelicheva, Mariya Y. Resolved: Academic Debate Should Be a Part of Political Science Curricula, Journal of Political Science Education 3:161-177, 2007. Publisher's Official Version <http://dx.doi.org/10.1080/15512160701338320>.

Open Access Version: <http://kuscholarworks.ku.edu/dspace/>.

Caine, R.N. and G. Caine. 1991. Making Connections: Teaching and the Human Brain. Alexandria, VA: ASCD.

Colbert, K. 1987. "The Effects of CEDA and NDT Debate Training on Critical Thinking Ability." Journal of the American Forensic Association 23:194-201.

Combs, H.W. and Bourne, S.G. 1994. "The Renaissance of Educational Debate: Results of a Five-Year Study of the Use of Debate in Business Education.” Journal on Excellence in College Teaching 5(1):57-67.

Comstock, Alzada. 1968. "The Cost of Debating." In Counterpoint: Debates about Debate, ed. Kruger, Arthur. N. Metuchen, NJ: The Scarecrow Press, 13-17.

Do, S. L. and D. L. Schallert. 2004. "Emotions and Classroom Talk: Toward a Model of the Role of Affect in Students' Experiences of Classroom Discussions." Journal of Educational Psychology 96:619-34.

Elliot, Lisa B. 1993. "Using Debates to Teach Psychology of Women." Teaching of Psychology 20(1):35-38.

Freeley, Austin J. 1971. Argumentation and Debate: Rational Decision Making. $3^{\text {rd }}$ ed. Belmont, CA: Wadsworth Publishing.

Freeley, Austin J. 1986. Argumentation and Debate: Rational Decision Making. $6^{\text {th }}$ ed. Belmont, CA: Wadsworth Publishing.

Gelder, Tim van. 2005. "Teaching Critical Thinking: Some Lessons from Cognitive Science.” College Teaching 53(1):41-46.

Green, Charles S., III and Hadley G. Klug. 1990. “Teaching Critical Thinking and Writing through Debates: An experimental Evaluation.” Teaching Sociology 18(4):46271. 
Omelicheva, Mariya Y. Resolved: Academic Debate Should Be a Part of Political Science Curricula, Journal of Political Science Education 3:161-177, 2007. Publisher's Official Version <http://dx.doi.org/10.1080/15512160701338320>.

Open Access Version: <http://kuscholarworks.ku.edu/dspace/>.

Hess, Diana. E. 2004. "Controversies about Controversial Issues in Democratic Education.” PS: Political Science and Politics 37(2):257-262.

Inoue, Narahiko. 1996. "Traditions of "Debate" in Japan." Bulletin of the Graduate School of Social and Cultural Studies, Kyushu University 2:149-161. http://www.rc.kyushu-u.ac.jp/ inouen/deb-trad.html (January 23, 2006).

Johnson, David W., and Roger T. Johnson. 1988. “Critical Thinking Through Structured Controversy." Educational Leadership (May):58-64.

Kruger, Arthur N. 1968. Counterpoint; Debates about Debate. Metuchen, N.J.: Scarecrow Press.

McBath, James H. 1963. "Introduction to Argument." In Argumentation and Debate: Principles and Practices, ed. James H. McBath. Holt, Rinehart and Winston, 3-14.

Moeller, Thomas G. 1985. "Using Classroom Debates in Teaching Developmental Psychology." Teaching of Psychology 12(4):207-209.

O'Brien, Rory. 1998. "An Overview of the Methodological Approach of Action Research”. http://www.web.net/ robrien/papers/arfinal.html\#_Toc26184650 (November 25, 2005).

Potter, David. 1963. "The Debate Tradition." In Argumentation and Debate. Principles and Practices. $2^{\text {nd }}$ edition, ed. McBath, James H. Holt, Rinehart and Winston, 14-33. Robinson, J. 1956. “A Recent Graduate Examines His Forensic Experience.” The Gavel 38: 62 .

Scriven, Michael, and Richard Paul. 2004. "Defining Critical Thinking: a Statement for the National Council for Excellence in Critical Thinking Instruction." Foundation for 
Omelicheva, Mariya Y. Resolved: Academic Debate Should Be a Part of Political Science Curricula, Journal of Political Science Education 3:161-177, 2007. Publisher's Official Version <http://dx.doi.org/10.1080/15512160701338320>.

Open Access Version: <http://kuscholarworks.ku.edu/dspace/>.

Critical Thinking. http://www.criticalthinking.org/aboutCT/definingCT.shtml (November 12, 2004).

Silberman, Mel. 1995. Twenty Active Learning Programmes:. Setting Learning Goals. San Diego: Pfeiffer \& Co.

Smith, Randolph A. 1990. “Are Peer Ratings of Student Debates Valid?” Teaching of Psychology 17(3):188-189.

Tsui, Lisa. 1999. "Courses and Instruction Affecting Critical Thinking." Research in Higher Education 40(2):185-200.

Thomson, Wayne N. 1968. "Discussion and Debate: A Re-Examination." In Counterpoint: Debates about Debate, ed. Kruger, Arthur N. Metuchen, NJ: The Scarecrow Press, 32-44.

Walker Melanie and Chris Warhurst. 2000. “'In Most Classes You Sit Around Very Quietly at a Table and Get Lectured at...' Debates, Assessment and Student Learning." Teaching in Higher Education 5(1):33-49.

1 The website of the International Debate Education Association contains succinct
description $\quad$ of different $\quad$ forms http://www.idebate.org/teaching/debate formats.php (January 23, 2006).

${ }^{2}$ There are at least four varieties of action research, all united by the same principles of inquiry and aimed at the resolution of different social problems. Traditional action research that originated in 1940s in the work of Kurt Lewin is concerned with labormanagement relations. Contextual action research, also known as action learning, has its roots in the work of Eric Trist and his colleagues who studied multi-organizational 
problems. Radical action research focuses on the questions of emancipation and the overcoming of power imbalances and aims at strengthening marginal groups in society. Finally, educational research is based on the idea that professional educators should be actively involved in community problem-solving. Its larger focus is on the development of curriculum, professional development of educators, and applying learning in various social contexts (O’Brien 1998).

${ }^{3}$ See, for example, Communication Across the Curriculum Program of the University of Pittsburg. http://www.cxc.pitt.edu/debatecontest.htm (January 23, 2006). 